\title{
Research on the Influential Factors of Entrepreneurial Intention of Residents in Tourist Destination
}

\author{
Xilin Zhang \\ Tourism and Historical Culture College \\ Zhaoqing University \\ Zhaoqing, P.R. China
}

\begin{abstract}
The factors that affect the tourist intention of tourism destination include the individual factors of entrepreneurs and the factors of entrepreneurial environment. Through a questionnaire survey in Chinese Lugu Lake tourist area, and by means of factor analysis and SPSS statistical analysis software, summarizes seven factors influencing tourism entrepreneurial intention: individual entrepreneurial self-efficacy, entrepreneurial ability to seize opportunity, ability of enterprise management; external evaluation, business development potential of entrepreneurial place attachment, commitment, for all kinds of business government trust. Finally, some suggestions are put forward to improve the tourism intention of residents in tourist areas.
\end{abstract}

Keywords-tourism entrepreneurship; entrepreneurial intention; influencing factors; factor analysis; Lugu lake of China

\section{INTRODUCTION}

Entrepreneurial intention reflects the degree of entrepreneur's entrepreneurial characteristics, and is the prerequisite for entrepreneurial activities. Tourism entrepreneurial intention is potential entrepreneurs to engage in tourism related business activities and not a subjective attitude, is a general description of people with similar characteristics of entrepreneurs and the extent of the people on the entrepreneurial attitude and ability, is an important predictor of tourism between entrepreneurial attitude and entrepreneurial behavior between tourism. The key factors affecting tourism to the local residents' Tourism entrepreneurial intention research, we can find a path to enhance tourism entrepreneur's entrepreneurial intention, so as to promote tourism to residents' better conversion from entrepreneurial intention for tourism business behavior.

\section{LITERATURE REVIEW}

Bird (1988) first put forward the idea of entrepreneurial intention [1]. Krueger et al (2000)[2] believes that entrepreneurial intention is a general description of people's subjective attitude and ability to start an undertaking. Thompson (2009)[3] points out that entrepreneurial intention refers to the belief that individuals plan to start a new enterprise. The factors that affect entrepreneurial intention can be divided into two categories: individual variables and environmental variables.
Proactive performance in individual personality effectively predicts entrepreneurial intentions (Kafetsions et al., 2009[4]), risk-taking tendencies and entrepreneurial intentions are related to a certain extent (Barbosa, et al., 2007[5]). At the same time, the findings support individual self-efficacy to play a mediating role in entrepreneurial intention (Barnir et al., 2011[6], Tsai, etc., 2016[7]). Most researchers came to the same conclusion that self-efficacy had a direct positive impact on entrepreneurial intentions (Naktiyok et al., 2010[8], Pihie, etc., 2013[9], Douglas, etc. (2013) [10]).

The success of an entrepreneur has something to do with its ability to do so. Individual decision making ability, opportunity identification and evaluation ability, communication skills and emotional intelligence can play a certain role in the prediction of entrepreneurial intentions (Hmieleski and Corbett, 2006[11]; Izquierdo and Buelens 2011[12])

Environmental factors can also influence the entrepreneurial intention of the entrepreneur to a certain extent. De, Pillis\&, Reardon (2007)[13] compares the differences in entrepreneurial intentions between two different cultures in Ireland and the United states. Wyrwich and others (2016)[14], by comparing two entrepreneurs in Germany, found that the external environment of entrepreneurship could stimulate individuals to have more entrepreneurial intentions.

From the existing research results, because of the different situations in different countries and regions, the key factors affecting the entrepreneurial intention are summarized and refined. This study attempts to these elements are classified and reestablished, the entrepreneurial factors of the relationship between environmental factors and individual factors, entrepreneurs and local governments as the assumption factors affecting entrepreneurs to carry out tourism business.

\section{RESEARCH AND ANALYSIS}

The questionnaire used Likert 5 point scale method, because of variables, entrepreneurial intention includes 12 entries, and independent variables include 32 entries. Select the Lugu Lake in Sichuan Province of China as a case study, from October 2016 to December 2016, take a phased 
approach of random sampling and quota sampling combined with issue 800 questionnaires, 730 questionnaires were collected, including 700 valid questionnaires. In the sex structure, the proportion of male samples was $59.29 \%$, female $40.71 \%$; age structure in young people, aged between $30-40$ years old accounted for $65.89 \%$ of the overall sample, followed by $41-50$, accounting for $18.43 \%$ of the overall sample survey of community residents; high school education accounted for $59.02 \%$, college and above accounted for the residents of the home to $26.14 \%$; the proportion of migrant labor more for 2 people, 3 people, 5 people, the proportion was $27.57 \%, 38.56 \%, 21.14 \%$. Respondents' entrepreneurial intention of descriptive statistics analysis results are shown in "Table I".

TABLE I. DESCRIPTIVE ANALYSIS OF ENTREPRENEURIAL INTENTION

\begin{tabular}{|l|l|l|l|}
\hline \multicolumn{1}{|c|}{ Variable all out to } & Average & \multicolumn{1}{|c|}{$\begin{array}{l}\text { Standard } \\
\text { deviation }\end{array}$} & Variance \\
\hline $\begin{array}{l}\text { Go } \\
\text { entrepreneurship }\end{array}$ & 2.98 & 1.457 & 2.123 \\
\hline $\begin{array}{l}\text { Entrepreneurship have great } \\
\text { possibilities for the future }\end{array}$ & 2.98 & 1.429 & 2.042 \\
\hline $\begin{array}{l}\text { Entrepreneurship even if it } \\
\text { failed }\end{array}$ & 2.97 & 1.415 & 2.002 \\
\hline $\begin{array}{l}\text { Entrepreneurship is the real } \\
\text { interest }\end{array}$ & 2.96 & 1.383 & 1.912 \\
\hline $\begin{array}{l}\text { Entrepreneurship with } \\
\text { assistants }\end{array}$ & 2.94 & 1.406 & 1.978 \\
\hline \begin{tabular}{l} 
Entrepreneurship with fund \\
\hline $\begin{array}{l}\text { Entrepreneurship with } \\
\text { preferential policy }\end{array}$
\end{tabular} & 2.94 & 1.385 & 1.918 \\
\hline $\begin{array}{l}\text { Entrepreneurship } \\
\text { technique }\end{array}$ & 2.91 & 1.380 & 1.905 \\
\hline $\begin{array}{l}\text { Do not give up with } \\
\text { painstaking effort }\end{array}$ & 2.91 & 1.412 & 1.993 \\
\hline Have near-term target & 2.89 & 1.436 & 2.063 \\
\hline $\begin{array}{l}\text { Want to be the enterprise's } \\
\text { administrator }\end{array}$ & 2.88 & 1.401 & 1.963 \\
\hline $\begin{array}{l}\text { Make adequate preparations } \\
\text { to entrepreneurship }\end{array}$ & 2.85 & 1.397 & 1.951 \\
\hline
\end{tabular}

\section{A. Validity Analysis of Scale}

Through statistics, it is found that the average number of each sub variable (upper and lower 25\%) is different, indicating that the two groups are independent variables, and each sub variable has an average difference. Then the significant independent sample test level of two groups in each sub variable average difference test showed that all sub variable Sig (bilateral) values were less than 0.05 , each variable has higher significance, which indicates that the scale has good construct validity, there is no need to eliminate sub variables.

\section{B. Factor Analysis of Variables}

In this study, first of all, the statistical analysis of the independent variables of tourism entrepreneurial factors is suitable for factor analysis. The calculated KMO value is 0.905, the Approx. Chi-Square value is 5708.563, and the Bartlett's Test of Sphericity values are 0.000. Principal component analysis was adopted in factor analysis, and 7 common factors were extracted by variance orthogonal rotation. Detailed statistics are summarized in "Table II".
According to the data in "Table II", "Table III", "Table IV", "Table V", "Table VI", "Table VII" and "Table VIII", 7 common factors extracted were named as follows:

- Will feel easy, the enterprise business process, the company founded clear details, formulate business plan, business confidence and self-evaluation of large enterprises may start their own 6 items grouped and renamed the factor of entrepreneurial self-efficacy. The variance contribution rate of this factor is $14.408 \%$.

TABLE II. FACTORS NAME \& ANALYSIS

\begin{tabular}{|l|l|l|l|}
\hline \multicolumn{1}{|c|}{$\begin{array}{c}\text { The name of } \\
\text { variable factor }\end{array}$} & $\begin{array}{c}\text { Factor } \\
\text { loading }\end{array}$ & \multicolumn{1}{|c|}{$\begin{array}{c}\text { The name of variable } \\
\text { factor }\end{array}$} & $\begin{array}{c}\text { Factor } \\
\text { loading }\end{array}$ \\
\hline $\begin{array}{l}\text { It's easy to } \\
\text { entrepreneurship }\end{array}$ & 0.624 & $\begin{array}{l}\text { draw up a project of } \\
\text { entrepreneurship }\end{array}$ & 0.571 \\
\hline $\begin{array}{l}\text { Master the process } \\
\text { of entrepreneurship }\end{array}$ & 0.666 & $\begin{array}{l}\text { Full of confidence to } \\
\text { entrepreneurship }\end{array}$ & 0.512 \\
\hline $\begin{array}{l}\text { Comprehend the } \\
\text { details of } \\
\text { entrepreneurship }\end{array}$ & 0.656 & $\begin{array}{l}\text { more likely to succeed in } \\
\text { more likely to }\end{array}$ & 0.524 \\
\hline
\end{tabular}

- Will be able to find the potential market, establish and maintain good relationship between local key figures, and can bear the pressure and change of entrepreneurship, facing financial difficulties still adhere to the investors and 5 items into a category, and renamed the entrepreneurial opportunity to grasp the power factor. The variance contribution rate of this factor is $11.744 \%$.

TABLE III. FACTORS NAME \& ANALYSIS

\begin{tabular}{|l|l|l|l|}
\hline $\begin{array}{l}\text { The name of } \\
\text { variable factor }\end{array}$ & $\begin{array}{l}\text { Factor } \\
\text { loading }\end{array}$ & $\begin{array}{l}\text { The name of variable } \\
\text { factor }\end{array}$ & $\begin{array}{l}\text { Factor } \\
\text { loading }\end{array}$ \\
\hline $\begin{array}{l}\text { Find the potential } \\
\text { markets }\end{array}$ & 0.537 & $\begin{array}{l}\text { Put up with the pressure } \\
\text { and variation during the } \\
\text { operation }\end{array}$ & 0.514 \\
\hline $\begin{array}{l}\text { Have a good } \\
\text { relationship with } \\
\text { potential investors }\end{array}$ & 0.614 & $\begin{array}{l}\text { Persist in it even if in } \\
\text { trouble }\end{array}$ & 0.713 \\
\hline $\begin{array}{l}\text { Establish with } \\
\text { relationship w } \\
\text { the local key figures }\end{array}$ & 0.562 & & \\
\hline
\end{tabular}

- The effective operation and management of content, rational use of human resources, the adjustment of property management objective and management ideas, to coordinate the relationship of interests and other related items 4 items classified as a class, and rename it the enterprise management ability factor. The variance contribution rate of this factor is $11.315 \%$.

TABLE IV. FACTORS NAME \& ANALYSIS

\begin{tabular}{|l|l|l|l|}
\hline $\begin{array}{c}\text { The name of variable } \\
\text { factor }\end{array}$ & $\begin{array}{c}\text { Factor } \\
\text { loading }\end{array}$ & $\begin{array}{c}\text { The name of variable } \\
\text { factor }\end{array}$ & $\begin{array}{c}\text { Factor } \\
\text { loading }\end{array}$ \\
\hline $\begin{array}{l}\text { Manage content } \\
\text { management } \\
\text { effectively }\end{array}$ & 0.688 & $\begin{array}{l}\text { Adjust the operation } \\
\text { target and mentality }\end{array}$ & 0.655 \\
\hline $\begin{array}{l}\text { Make reasonable use of } \\
\text { human, financial and } \\
\text { material resources }\end{array}$ & 0.590 & $\begin{array}{l}\text { coordinate relations } \\
\text { between various of } \\
\text { assignments and } \\
\text { benefits }\end{array}$ & 0.573 \\
\hline
\end{tabular}


- $\quad$ This place famous and here than in other places have advantages, this place is good, there are many people envy" and other 4 items into a category, and rename it the business development potential factor. The variance contribution rate of this factor is $10.174 \%$.

TABLE V. FACTORS NAME \& ANALYSIS

\begin{tabular}{|l|l|l|l|}
\hline $\begin{array}{c}\text { The name of variable } \\
\text { factor }\end{array}$ & $\begin{array}{c}\text { Factor } \\
\text { Loading }\end{array}$ & $\begin{array}{c}\text { The Name of } \\
\text { Variable Factor }\end{array}$ & $\begin{array}{c}\text { Factor } \\
\text { Loading }\end{array}$ \\
\hline This place is famous & 0.567 & It's good place to live & 0.612 \\
\hline $\begin{array}{c}\text { It's better than } \\
\text { anywhere else }\end{array}$ & 0.587 & It's an enviable place & 0.564 \\
\hline
\end{tabular}

- The "I have a natural feeling of this place, I think this place is like my home, this place is my own part, I was part of this place" 4 items into a category, and rename it the place attachment factor. The variance contribution rate of this factor is $9.229 \%$.

TABLE VI. FACTORS NAME \& ANALYSIS

\begin{tabular}{|l|l|l|l|}
\hline $\begin{array}{c}\text { The name of variable } \\
\text { factor }\end{array}$ & $\begin{array}{c}\text { Factor } \\
\text { loading }\end{array}$ & $\begin{array}{c}\text { The name of variable } \\
\text { factor }\end{array}$ & $\begin{array}{c}\text { Factor } \\
\text { Loading }\end{array}$ \\
\hline $\begin{array}{l}\text { I have natural emotion } \\
\text { to this place }\end{array}$ & 0.579 & $\begin{array}{l}\text { This place is a part of } \\
\text { me }\end{array}$ & 0.537 \\
\hline $\begin{array}{l}\text { I regard this place as } \\
\text { my home }\end{array}$ & 0.548 & I'm part of this place & 0.564 \\
\hline
\end{tabular}

- "I am willing to stay here long, I hope to witness the development here, here in my future planning is very important in my future, and here there is a close relationship between the" 4 items into a category, and renamed the entrepreneurial commitment factor. The variance contribution rate of this factor is $8.905 \%$.

TABLE VII. FACTORS NAME \& ANALYSIS

\begin{tabular}{|l|l|l|l|}
\hline $\begin{array}{c}\text { The name of variable } \\
\text { factor }\end{array}$ & $\begin{array}{c}\text { Factor } \\
\text { loading }\end{array}$ & \multicolumn{1}{c|}{$\begin{array}{c}\text { The name of } \\
\text { variable factor }\end{array}$} & $\begin{array}{c}\text { Factor } \\
\text { loading }\end{array}$ \\
\hline $\begin{array}{l}\text { I would like to stay } \\
\text { here for a long time }\end{array}$ & 0.568 & $\begin{array}{l}\text { It plays an important } \\
\text { role in my future plan }\end{array}$ & 0.589 \\
\hline $\begin{array}{l}\text { I would like to be the } \\
\text { witness of the place } \\
\text { development }\end{array}$ & 0.571 & $\begin{array}{l}\text { It has closely relation } \\
\text { with my future }\end{array}$ & 0.573 \\
\hline
\end{tabular}

- The local trust business management department, the local environmental protection departments, local housing and land departments, trust the local town government and trust the local village / neighborhood and other 5 items into a category, and renamed the business trust factor. The variance contribution rate of this factor is $8.851 \%$.

TABLE VIII. FACTORS NAME \& ANALYSIS

\begin{tabular}{|l|l|l|l|}
\hline \multicolumn{1}{|c|}{$\begin{array}{c}\text { The name of } \\
\text { variable factor }\end{array}$} & $\begin{array}{c}\text { Factor } \\
\text { loading }\end{array}$ & $\begin{array}{c}\text { The name of variable } \\
\text { factor }\end{array}$ & $\begin{array}{c}\text { Factor } \\
\text { loading }\end{array}$ \\
\hline $\begin{array}{l}\text { Trust the local } \\
\text { business management }\end{array}$ & 0.653 & $\begin{array}{l}\text { Trust the local town } \\
\text { government }\end{array}$ & 0.958 \\
\hline $\begin{array}{l}\text { Trust the local } \\
\text { ministry of } \\
\text { environment }\end{array}$ & 0.665 & $\begin{array}{l}\text { Trust the local villagers } \\
\text { committee/neighborhood } \\
\text { committee }\end{array}$ & 0.960 \\
\hline $\begin{array}{l}\text { Trust the local } \\
\text { housing land } \\
\text { management } \\
\text { department }\end{array}$ & 0.528 & & \\
\hline
\end{tabular}

\section{CONCLUSION}

In the basis of the existing research results, this study found that the overall influence factors of tourism to the local residents of entrepreneurial intention can be summarized as the following 7 aspects: individual entrepreneurial performance has its own sense of height, entrepreneurial ability to grasp the opportunity, the size of enterprise management ability; entrepreneurs of the external evaluation of entrepreneurial business development potential, entrepreneurial quality on entrepreneurial the place attachment degree, entrepreneurial commitment strength, entrepreneurs of various government agencies trust degree.

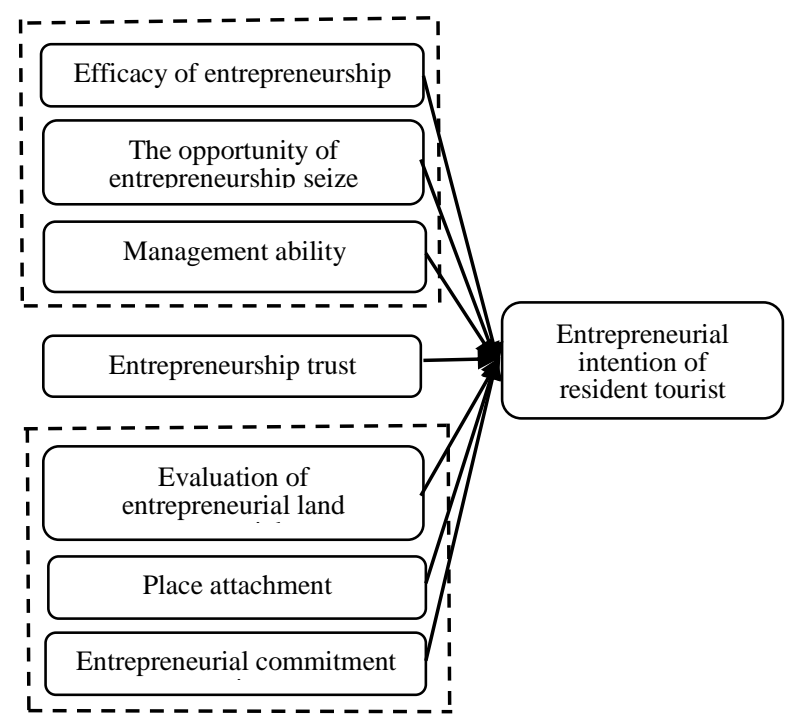

Fig. 1. The motivation composition that influences tourism intention.

These 7 factors affect the level of entrepreneurial intention of residents in tourism. Among these 7 factors, the three factors, entrepreneurial efficacy, entrepreneurial opportunity, management ability, are related to the individual's own ability and self-confidence. The three factors of entrepreneurial development potential evaluation, entrepreneurial place attachment and entrepreneurial commitment belong to the entrepreneur's cognition, emotion and corresponding behavior. The factor of "trust in entrepreneurial government institutions" is the judgment and recognition of the entrepreneur's Micro entrepreneurial environment and entrepreneurial policies and institutions. Therefore, in order to improve the tourist's entrepreneurial intention level, we can consider the following three directions to carry out the targeted work.

First of all, we should stimulate and improve the individual entrepreneurial self-efficacy of residents in tourism areas, and raise the level of individual entrepreneurial ability. Only to enhance self-efficacy, in order to ensure it has enough confidence to entrepreneurship, can still be enough to solve the problem in the face of unknown difficulties may arise when confidence, confidence decided to complete the entire business process, to achieve business objectives. Improving the individual entrepreneurial ability of the tourist destination will help the entrepreneur to complete the business plan, complete the business and 
continue to operate. For the residents of tourist areas, the development of tourism in the local tourist areas has many opportunities for entrepreneurship, and the promotion of enterprise management ability is more urgent and important.

Secondly, strengthen the local identity of residents in tourist areas and promote local attachment. The stronger the local identity is, the stronger the individual's place attachment is. Strengthen community residents place identity, not only can enhance the residents' positive evaluation on the local business development potential, but also can stimulate residents re understanding of the local culture, nature, ecological environment and other advantages, strengthen the individual recognition of the usual production and living environment, is helpful to the improvement of self-efficacy is more important; can enhance the entrepreneurial environment on entrepreneurial recognition, their entrepreneurial development into the local development.

Finally, we should deepen the trust of local residents at all levels of local government organizations in support of tourism entrepreneurship, improve the confidence of residents in tourist areas for government organizations to support tourism entrepreneurship, promote cooperation among residents and government organizations, and promote the formation of stronger entrepreneurial intentions and higher expectations of entrepreneurship.

\section{REFERENCES}

[1] Barbara Bird, "Implementing entrepreneurial ideas: the case for intention," Academy of Management Review, vol. 13, pp. 442-453, July 1988.

[2] Krueger N F, Reilly, M D, Carsrud A L, "Competing models of entrepreneurial intentions," Journal of Business Venturing, vol. 15, pp. 411-432, September 2000

[3] Thompson E R. "Individual entrepreneurial intent: construct clarification and development of an internationally reliable metric," Entrepreneurship Theory and Practice, vol. 33, pp. 669-694, May 2009.

[4] Zampetakis, L. A., Kafetsios, K., Bouranta, N., Dewett, T., Moustakis, V.S, "On the relationship between emotional intelligence and entrepreneurial attitudes and intentions," International Journal of Entrepreneurial Behavior \& Research, vol. 15, pp. 595-618, 2009.

[5] Barbosa S D, Gerhardt M W, Kickul J R, "The Role of cognitive style and risk preference on entrepreneurial self-efficacy and entrepreneurial intentions," Journal of Leadership \& Organizational Studies, vol. 13, pp. 84-104, May 2007.

[6] Barnir A, Watson W E, Hutchins H M, "Mediation and moderated mediation in the relationship among role models, self-efficacy, entrepreneurial career intention, and gender," Journal of Applied Social Psychology, vol. 41, pp. 270-2978, February 2011.

[7] Tsai K H, Chang H C, Peng C Y, "Extending the link between entrepreneurial self-efficacy and intention: a moderated mediation model," International Entrepreneurship \& Management Journal, vol. 12, pp. 1-19, June 2016.

[8] Naktiyok A, Karabey C N, Gulluce A C, "Entrepreneurial selfefficacy and entrepreneurial intention: the Turkish case," International Entrepreneurship \& Management Journal, vol. 6, pp. 419-435, December 2010.

[9] Pihie $\mathrm{Z}$ a L, Bagheri A, "Self-efficacy and entrepreneurial intention: the mediation effect of self-regulation," Vocations and Learning, vol. 6, pp. 385-401, October 2013.

[10] Douglas E J, Fitzsimmons J R, "Intrapreneurial intentions versus entrepreneurial intentions: distinct constructs with different antecedents," Small Business Economics, vol. 41, pp. 115-132, June 2013.

[11] Hmieleski K M, Corbett A C, "Proclivity for improvisation as a predictor of entrepreneurial intentions," Journal of Small Business Management, vol. 44, pp. 45-63, January 2006.

[12] Izquierdo E, Buelens M, "Competing models of entrepreneurial intentions: the influence of entrepreneurial self-efficacy and attitudes," International Journal of Entrepreneurship \& Small Business, vol. 13, pp. 75-91, May 2011.

[13] Pillis E D, Reardon K K, "The influence of personality traits and persuasive messages on entrepreneurial intention: A cross - cultural comparison," Career Development International, vol. 12, pp. 382-396 2007.

[14] Wyrwich M, Stuetzer M, Sternberg R, "Entrepreneurial role models, fear of failure, and institutional approval of entrepreneurship: a tale of two regions," Small Business Economics, vol. 46, pp. 467-492, March 2016. 